JPdK Volume 3 Nomor 2 Tahun 2021 Halaman 117-121

JURNAL PENDIDIKAN dan KONSELING

Research \& Learning in Primary Education

UNIVERSITAS

\title{
Penerapan Pembelajaran Kontekstual Dalam Meningkatkan Kemampuan Pemecahan Masalah Matematika di MTs Ma'arif Bandar
}

\author{
Elzra Melasevix ${ }^{1}$, Haidar Ali Asnawi ${ }^{2}$, Jam Jalani Nur Alami ${ }^{3}$, Ika Hidayatul Masynuah ${ }^{4}$, Ridho \\ Arianto Nanda Putra ${ }^{5}$, Darmadi ${ }^{6}$
}

Program Studi Pendidikan Matematika

Fakultas Keguruan dan Ilmu Pendidikan

Universitas PGRI Madiun

Email : gelorka09@gmail.com, Haidarali300900@gmail.com, alaminur397@ gmail.com, dpurnomo181@gmail.com, ridhoariyanto2@gmail.com, darmaixmadiun@gmail.com

\begin{abstract}
Abstrak
Pendidikan adalah hal yang utama yang menjadi peran penting bagi kehidupan anak di Indonesia. Dengan adanya pendidikan dapat meningkatkan kualitas sumber daya manusia yang dimiliki oleh seorang siswa. Namun beberapa hal masih menjadi penghambat tercapainya tujuan pendidikan yang diantaranya adalah kurangnya pemahaman terhadap materi-materi yang tidak disukai oleh siswa. Pelajaran matematika masih menjadi pembelajaran yang kurang disukai oleh siswa sehingga dalam proses pembelajarannya siswa kurang mampu memahami konsep dan pemecahan suatu masalah matematika. Untuk mengatasi permasalahan tersebut diperlukan suatu proses pembelajaran yang dapat meningkatkan pemahaman siswa terhadap pemahaman dan pemecahan soal matematika. Penelitian ini dilakukan untuk meningkatkan kemampuan pemahaman dan pemecahan masalah matematika siswa dengan menerapkan metode pembelajaran kontekstual. Jenis penelitian yang digunakan adalah penelitian deskriptif kualitatif. Subjek dari penelitian ini adalah siswa kelas MTs Ma'arif Bandar sebagai subjek yang akan menerima tindakan. Dalam memperoleh data, peneliti menggunakan dua cara yaitu tes tulis pada siswa dan melakukan wawancara. Hasil penelitian ini menunjukkan bahwa penerapan pembelajaran kontekstual kepada siswa kelas VII SMP Negeri Bandar sangat mempengaruhi pemahaman dan pemecahan masalah matematika.
\end{abstract}

Kata Kunci $\quad$ : Pendekatan Kontekstual, Pemecahan Masalah Matematika

\begin{abstract}
Education is the main aspect that plays an important role in the lives of children in Indonesia. The existence of education can improve the quality of human resources owned by a student. However, several things still become obstacles to achieving educational goals, including a lack of understanding of materials in the teaching and learning process. The mathematics lessons are still less favored by students so that in the teaching and learning process, they are less able to understand the concept and solve a mathematical problem. In order to solve these problems, an appropriate teaching and learning process is needed that can improve students' understanding and solving mathematical problems. This research was conducted to improve students' mathematical understanding and problem-solving skills by applying contextual learning methods. The type of research used is descriptive qualitative research. The subjects of this study were seventh-grade students of MTs Ma'arif Bandar as the subject who would receive the action. In conducting the data, the researcher used two kinds of methods, consist of a written test on students and conducting
\end{abstract}


interviews. The results of this study indicate that the application of contextual learning to the seventh-grade students of MTs Ma'arif Bandar greatly affects the understanding and solving of mathematical problems.

Keywords : Contextual Approach, Mathematical Problem Solving

\section{PENDAHULUAN}

Pendidikan adalah sesuatu hal yang terikat dengan pembelajaran. Pembelajaran adalah proses interaksi antar anak dengan anak, anak dengan sumber belajar, dan anak dengan pendidik (Daryanto, 2014:1). Dalam suatu pembelajaran tidak akan terlepas dari belajar. Belajar sebagai suatu proses yang mana suatu kegiatan berasal atau berubah lewat reaksi dari suatu situasi yang dihadapi dengan karakteristikkarakteristik dari perubahan-perubahan aktifitas tersebut tidak dapat dijelaskan dengan dasar kecenderungan-kecenderungan reaksi asli,kematangan atau perubahan-perubahan sementara dari organisme.

Matematika memiliki peranan penting dalam segala aspek kehidupan terutama dalam meningkatkan daya pikir manusia, sehingga matematika merupakan salah satu mata pelajaran yang diwajibkan di setiap jenjang sekolah mulai dari SD sampai SMA (Sumartini, 2016). Dalam setiap jenjang sekolah mata pelajaran matematika adalah sesuatu hal yang wajib dan pasti ada. Mustafa (Tri Wijayanti, 2011) menyebutkan bahwa matematika adalah ilmu tentang kuantitas, bentuk, susunan, dan ukuran, yang utama adalah metode dan proses untuk menemukan dengan konsep yang tepat dan lambang yang konsisten, sifat dan hubungan antara jumlah dan ukuran, baik secara abstrak, matematika murni atau dalam keterkaitan manfaat pada matematika terapan. pada saat ini mata pelajaran matematika masih menjadi momok buruk bagi siswa di berbagai tingkatan. pembelajaran matematika masih dianggap pembelajaran yang menakutkan dan sulit untuk dipahami, dengan mindset yang sudah tertanam pada ada diri seorang pelajar tentang hal buruk tersebut pembelajaran matematika berlangsung secara tidak maksimal beberapa sebab diantaranya yaitu materi sulit dipahami, kurangnya minat belajar siswa terhadap pembelajaran matematika.

Hal ini dapat terjadi karena penyampaiannya pembelajaran matematika yang terlalu monoton dan tidak bervariatif menyebabkan pelajar kurang menyukai pembelajaran matematika karena merasa bosan. Hal ini selaras dengan pendapat Nasution yang menyatakan bahwa pembelajaran berjalan lancar bila ada niat dan apabila anak-anak malas belajar mereka akan gagal karena tidak adanya minat.

Mempelajari matematika tidak hanya memahami konsepnya saja atau prosedurnya saja, akan tetapi banyak hal yang dapat muncul dari hasil proses pembelajaran matematika (Mawaddah \& Anisah, 2015). Dari hal tersebut dibutuhkan suatu metode pembelajaran yang dapat meningkatkan semangat siswa untuk dapat memahami konsep dan pemecahan pembelajaran matematika dengan lebih baik. salah satu hal yang dapat digunakan untuk meningkatkan kemampuan dalam pemahaman konsep dan memecahkan soal matematika yaitu dengan belajar menggunakan pendekatan kontekstual.

Menurut (kadir, 2013) Model kontekstual merupakan konsep belajar yang berangga[an bahwa anak akan belajar lebih baik jika lingkungan diciptakan secara ilmiah, artinya belajar akan lebih bermakna jika anak "bekerja" dan "mengalami" sendiri apa yang dipelajarinya, bukan sekedar "mengetahuinya". dengan cara ini diharapkan peserta didik dapat lebih optimal dalam memahami konsep atau pemecahan masalah yang berkaitan dengan pembelajaran matematika. Salah satu kelebihan pembelajaran dengan menggunakan pendekatan kontekstual yaitu sama dengan melibatkan 7 komponen utama suatu pembelajaran dalam 1 rangkaian, 
tujuh komponen efektif yaitu konstruktivisme, inkuiri, bertanya, belajar permodelan, dan penilaian yang sebenarnya. Menurut Johnson (2002: 67) Pembelajaran kontekstual adalah sebuah proses pendidikan yang menolong para siswa melihat makna di dalam materi akademik yang mereka pelajari dengan cara menghubungi subjek-subjek 7 akademik yang mereka pelajari dengan konteks kehidupan sehari-hari mereka, yakni konteks pribadi, sosial, dan budaya. sehingga melalui tahapan-tahapan tersebut diharapkan peserta didik dapat lebih mudah untuk memahami pembelajaran tentang pemahaman konsep dan pemecahan masalah matematika untuk mendapatkan hasil yang lebih baik.

Menurut (Haryani, 2011). Pemecahan masalah merupakan proses mental tingkat tinggi dan memerlukan proses berpikir yang lebih kompleks. Kemampuan pemecahan masalah juga dapat diartikan kemampuan siswa dalam memecahkan masalah yang kompleks dan nonrutin. (Rambe Arjuna Yahdil Fauza \& Afri, 2020). Selain itu Kemampuan pemecahan masalah merupakan potensi yang dimiliki seseorang atau siswa dalam menyelesaikan soal. (Kurniawan, Nindiasari, \& Set, 2020)

\section{METODOLOGI PENELITIAN}

Metode yang digunakan dalam penelitian ini deskriptif kualitatif. Adapun yang dimaksud dengan penelitian deskriptif kualitatif adalah suatu penelitian yang memiliki tujuan untuk memberikan gambaran secara jelas kepada pembaca hal tersebut sesuai dengan pengertian Metode Penelitian Diskriptif Kualitatif menurut Sukmadinata (2017, hlm. 73) adalah metode yang digunakan untuk mendeskripsikan dan menggambarkan fenomena-fenomena yang ada, baik bersifat alamiah maupun rekayasa manusia, yang lebih memperhatikan mengenai karakteristik, kualitas, keterkaitan antar kegiatan.

Subjek penelitian ini adalah tiga belas siswa MTs Ma'arif Bandar, Penelitian dilaksanakan pada tanggal 12 Juni 2021. Karena penelitian ini termasuk dalam penelitian kualitatif maka instrumen penelitian yang digunakan adalah peneliti itu sendiri. Adapun cara untuk memperoleh data pada penelitian ini adalah dengan menggunakan cara tes tulis pada siswa dengan pertanyaan terkait dengan penerapan pembelajaran matematika pada kehidupan sehari hari. Kemudia dilanjutkan dengan tes wawancara untuk memperkuat alasan dari jawaban subjek pada tes tulis sebelumnya.

Adapun teknik analisis data yang digunakan pada penelitian ini adalah reduksi data, setelah itu penyajian data, dan dilanjutkan dengan penarikan kesimpulan. Penyajian data dilakukan dengan cara mendeskripsikan data yang sudah didapat dianalisis sesuai dengan indikator pemecahan masalah pada matematika. Adapun untuk melakukan penarikan kesimpulan adalah melakukan pembandingan antara sebelum dan sesudah adanya penelitian.

\section{HASIL DAN PEMBAHASAN}

Dari hasil uji soal dan hasil wawancara dari permasalahan dapat diketahui bahwa peneliti menemukan hal-hal yang berkaitan dengan proses pemecahan soal matematika dengan tahapan pendekatan pembelajaran yang digunakan. Berdasarkan hasil, peneliti memberikann soal sebagai berikut :

1. Harga 2 pensil dan 4 penggaris adalah Rp3.800 sedangkan harga 7 pensil dan 3 penggaris adalah Rp5.325 berapa harga 3 pensil dan 2 penggaris?

2. Harga 4 buah permen $\mathrm{A}$ dan 3 buah permen B adalah Rp2.500 sedangkan harga 2 buah permen A dan 7 buah permen B adalah Rp2.900 berapakah harga 2 lusin permen A dan 4 lusin B?

3. Sebuah kapal berlayar sejauh $100 \mathrm{~km}$ ke arah barat kemudian berbelok ke arah selatan sejauh $75 \mathrm{~km}$ jarak terpendek kapal tersebut dari titik keberangkatan?

4. Sebuah tiang tingginya $12 \mathrm{~m}$ berdiri tegak diatas tanah datar dari ujung atas 
hingga ditarik seutas tali sebuah patok pada tanah jika panjang tali $15 \mathrm{~m}$ maka jarak patok dengan pangkal tiang bagian bawah adalah?

Setelah diadakannya tes tersebut peneliti menganalisis jawaban pada soal latihan dan terdapat perpedaan kecepatan pengumpulan hasil tes. Setelah di telusuri dalam pengerjaan soal latihan, melihat adanya perbedaan kecepatan pengumpulan hasil tes tersebut kami melakukan wawancara kepada beberapa mahasiswa untuk menanyakan apakah yang mempengaruhi kecepatan pengerjaan dari masing-masing siswa.

Dari hasil wawancara yang diberikan ada beberapa siswa tersebut salah satu penyebab dari perbedaan pengumpulan latihan soal adalah pemahaman tentang konsep soal yang dirasa terlalu rumit dan sulit.

Wawancara dengan Subjek 1 (siswa yang mengumpulkan soal lebih lama dibandingkan siswa lainnya) untuk mengetahui jawaban alasan siswa disajikan dalam wawancara berikut.

Peneliti : Bagimana soalnya? mudah atau sulit?

Subjek 1 : Tadinya bingung saat menuliskan kalimat matematikanya. Jadi mengerjakannya lama. Setelah mengingat cara menuliskan kalimat matematikanya sudah paham langsung bisa mengerjakan.

Peneliti : Bagaimana cara menuliskan kalimat matematikanya?

Subjek 1 : di bayangkan jika kita mengalami langsung.

Dari hasil wawancara diatas adanya perpedaan waktu dalam mengumpulkan hasil pengerjaan latihan soal adalah kurangnya pemahaman terhadap soal secara konseptual. Dari hasil wawancara tersebut dapat diketahui bahwa objek 1 telah menerapkan pembelajaran dengan pendekatan kontekstual namun belum dilakukan secara maksimal karena adanya nya proses berpikir yang belum menetap ke satu tujuan yaitu dengan menggunakan kontekstual.
Berbeda halnya dengan hasil wawancara dengan subjek 2 (siswa yang mengumpulkan hasil pengerjaan di urutan pertama) yang disajikan dalam wawancara berikut :

Peneliti : Bagimana pengerjaan soalnya? Apakah ada kesulitan?

Subjek 2 : Tidak Bu, sudah cukup paham. karena biasanya saat mengerjakan soal cerita harus tau apa yang sedang dicari penyelesaiannya?

Peneliti : bagaimana kamu tau apa yang harus dicari penyelesaiannya jika dalam soal yang kamu kerjakan sekarang ini?

Subjek 1 : menuliskan model matematikanya dengan memahami soal seakan akan saya mengalami apa yang dimaksud di soal tersebut.

Dari pernyataan tersebut dapat diketahui bahwa siswa yang memiliki proses berpikir melakukan penyelesaian soal menggunakan pendekatan kontekstual memiliki kecepatan lebih baik dalam pengerjaan soal dibandingkan dengan siswa yang tidak secara langsung menggunakan dengan proses pendekatan kontekstual dimana hal ini berpengaruh terhadap kecepatan pengerjaan dan pemahaman konsep soal yang diberikan.

Dari pembahasan yang telah dipaparkan diketahui bahwa kurangnya pemahaman konsep terhadap penyelesaian suatu masalah akan mempengaruhi siswa dalam pengerjaan suatu soal tersebut. Selain itu model pendekatan yang digunakan untuk menyelesaikan suatu masalah juga berpengaruh terhadap hasil yang yang didapat.

\section{KESIMPULAN}

Berdasarkan pembahasan dari hasil penelitian yang dilakukan dapat disimpulkan bahwa :

1. Pemahaman soal dapat dilakukan dengan melakukan konsep pendekatan pembelajaran.

2. Pendekatan kontekstual sangat efektif dalam penerapan pemahaman konsep soal matematika 
3. Dengan adanya penggunaan pendekatan kontekstual dapat mempengaruhi hasil belajar siswa.

Dengan itu berdasarkan hasil penelitian tersebut maka dapat diketahui bahwa penggunaan pendekatan kontekstual dalam menyelesaikan soal matematika sangat berpengaruh terhadap proses pemecahan soal matematika yang diberikan.

\section{DAFTAR PUSTAKA}

Haryani, D. (2011). PEMBELAJARAN MATEMATIKA DENGAN PEMECAHAN MASALAH UNTUK MENUMBUHKEMBANGKAN KEMAMPUAN BERPIKIR KRITIS SISWA. Prosiding Seminar Nasional Penelitian, Pendidikan dan Penerapan MIPA, 121-126.

Kadir, A. (2013). KONSEP PEMBELAJARAN KONTEKSTUAL DI SEKOLAH. Dinamika Ilmu, 17-38.

Kurniawan, R. I., Nindiasari, H., \& Set, Y. (2020). ANALISIS KEMAMPUAN PEMECAHAN MASALAH MATEMATIS DENGAN MENGGUNAKAN PEMBELAJARAN DARING. Wilangan Jurnal Inovasi dan Riset Pendidikan Matematika, 150-160.

Mawaddah, S., \& Anisah, H. (2015). KEMAMPUAN PEMECAHAN MASALAH MATEMATIS SISWA PADA PEMBELAJARAN MATEMATIKA DENGAN MENGGUNAKAN MODEL PEMBELAJARAN GENERATIF (GENERATIVE LEARNING) DI SMP. Jurnal Pendidikan Matematika, 166-175.

Rambe Arjuna Yahdil Fauza, A. Y., \& Afri, L. D. (2020). ANALISIS KEMAMPUAN PEMECAHAN MASALAH MATEMATIS SISWA DALAM MENYELESAIKAN SOAL MATERI BARISAN DAN DERET. AXIOM JURNAL PENDIDIKAN \& MATEMATIKA, 175-187.
Sumartini, T. S. (2016). Peningkatan Kemampuan Pemecahan Masalah Matematis Siswa melalui Pembelajaran Berbasis Masalah. Jurnal Pendidikan Matematika, 148 